\title{
First case report of Ascaridia hermaphrodita (Froelich, 1789) Railliet \& Henry, 1914 (Nematoda Ascaridoidea) in the Brazilian hyacinth macaw, Anodorhynchus hyacinthinus (Latham, 1790) Spix, 1824 (Aves, Psitacidae)
}

\author{
Primeiro relato de Ascaridia hermaphrodita (Froelich, 1789) Railliet \& \\ Henry, 1914 (Nematoda Ascaroidea) em arara azul, Anodorhynchus \\ hyacinthinus (Latham, 1790) Spix, 1824 (Aves, Psitacidae)
}

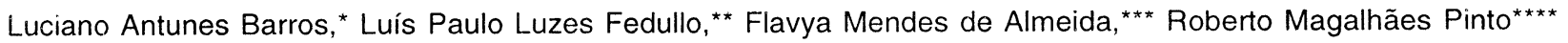

\begin{abstract}
Resumo
Um caso de parasitismo por Ascaridia hermaphrodita (Froelich, 1789) no psitacideo Anodorhynchus hyacinthinus (Latham, 1790), arara azul, com dados clínicos e patológicos é apresentado.
\end{abstract}

Palavras-chave: Ascaridia hermaphrodita; Nematoda; Anodorhynchus hyacinthinus.

\begin{abstract}
A case of parasitism due to the nematode Ascaridia hermaphrodita (Froelich, 1789) in the psittacid hyacinth macaw, Anodorhynchus hyacinthinus (Latham, 1790), with data on clinical and pathological findings, is reported.
\end{abstract}

Keywords: Ascaridia hermaphrodita; Nematoda; Anodorhynchus hyacinthinus.

The helminth fauna of Brazilian psittacid birds has been reported by Travassos (1930), Pereira (1933), Freitas \& Mendonça (1952), Serra-Freire \& Bianchini (1978), Pinto et al. (1993) and Vicente et al. (1995).

The psittacid can harbor mainly nematodes infecting the digestive tract, eyes, tendons of

feet and few are the data on their potential of pathogenicity to these hosts. The psittacid are very remarkable birds due to their bright colors and easy domestication. Thus, they are permanently endangered either considering illegal commercialization or the degradation of natural environments.

The hyacinth macaw is referred in the interior of north Brazil from the Tapajós River east to Maranhão and south through western Bahia and Goiás to Minas Gerais and Mato Grosso, where it nests in hollow trunks and feeds basically on fruits, seeds and nuts (Forshaw, 1977).
The present case reports to a captive female specimen of the hyacinth macaw attended at a veterinary facility in Rio de Janeiro, State of Rio de Janeiro, Brazil. The bird showed signs of ataxia and watery feces. Supportive care consisted in the administration of sulfaguanidine and Lactated Ringer's solution (LRS). At the same day the bird died and was necropsied. Ninety-six nematode specimens were recovered from the small intestine where gross lesions, consisting of a discret congestion of the intestinal mucosa and an increase in the mucus production, were observed.

Nematodes were fixed in hot A.F.A.(acetic acid + formaldehyde + ethanol solution) Processing of specimens for study and their further identification are in accordance with Pinto et al. (1993). Photomicrographs of nematodes and cross-sections were obtained in Axiophot Differential Interference Contrast (DIC) and brightfield microscopy systems, respectively. Six specimens, three males and three females, were deposited

\footnotetext{
* Laboratório de Helmintos Parasitos de Vertebrados, Departamento de Helmintologia, Instituto Oswaldo Cruz, Av. Brasil 4365, 21045-900, Rio de Janeiro, Brasil.

** Universidade Estácio de Sá, Rua do Bispo, 83, CEP 20261-060, Rio de Janeiro,RJ, Brasil.

*** Fundação Rio-Zoo, Quinta da Boa Vista, CEP 20261-060, Rio de Janeiro, RJ, Brasil.

${ }^{\star * \star \star}$ Corresponding author. CNPq Research fellow. Proc. no. 300.374/80-1.
} 
in the Helminthological Collection of the Oswaldo Cruz Institute (CHIOC) no. 34434 (wet material). Classification of the host follows Forshaw (1977) and Pinto (1978).

Fragments of the small intestine were removed and immediately fixed in formalin. The material was then routinely processed for parafin embedding. Five $\mathrm{mm}$ thick sections were stained with haematoxylin and eosin.

This is the first report of the nematode Ascaridia hermaphrodita (Figs. 1-4) parasitizing the psittacid Anodorhynchus hyacinthinus, since the most recent data on the helminth parasites of the hyacinthine macaw are those of Martinez et al. (1999) that refer only to Ascaridia spp., in captive A. hyacinthinus in Argentina.

Histopathological examination revealed an intense erosive process of the intestinal mucosa with inflammatory cells infiltration with predominance of granulocytes (heterophils and eosinophils) mainly distributed on the surface of the mucosa (Figs. 5-6).
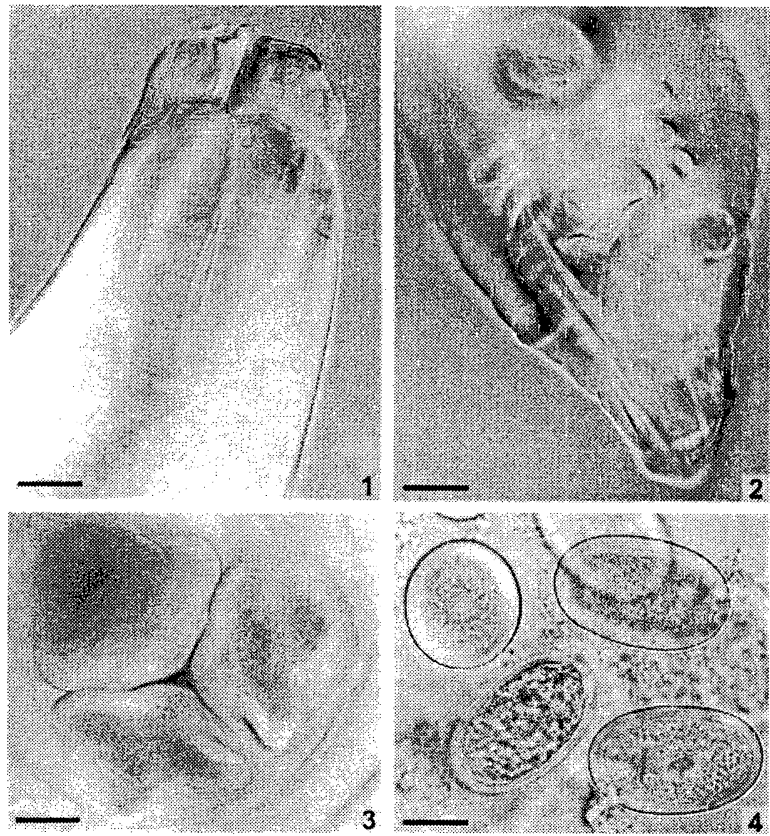

Figs 1-4. (1) Ascaridia hermaphrodita (Froelich, 1789) Railliet \& Henry, 1914, anterior extremity of female, lateral view. Bar $=$ $0.10 \mathrm{~mm}$; (2) posterior of male, lateral view. Bar $=0.10 \mathrm{~mm}$; (3) head of female, en face view. Bar $=0.05 \mathrm{~mm}$; (4) eggs in utero. Bar $=0.02 \mathrm{~mm}$.
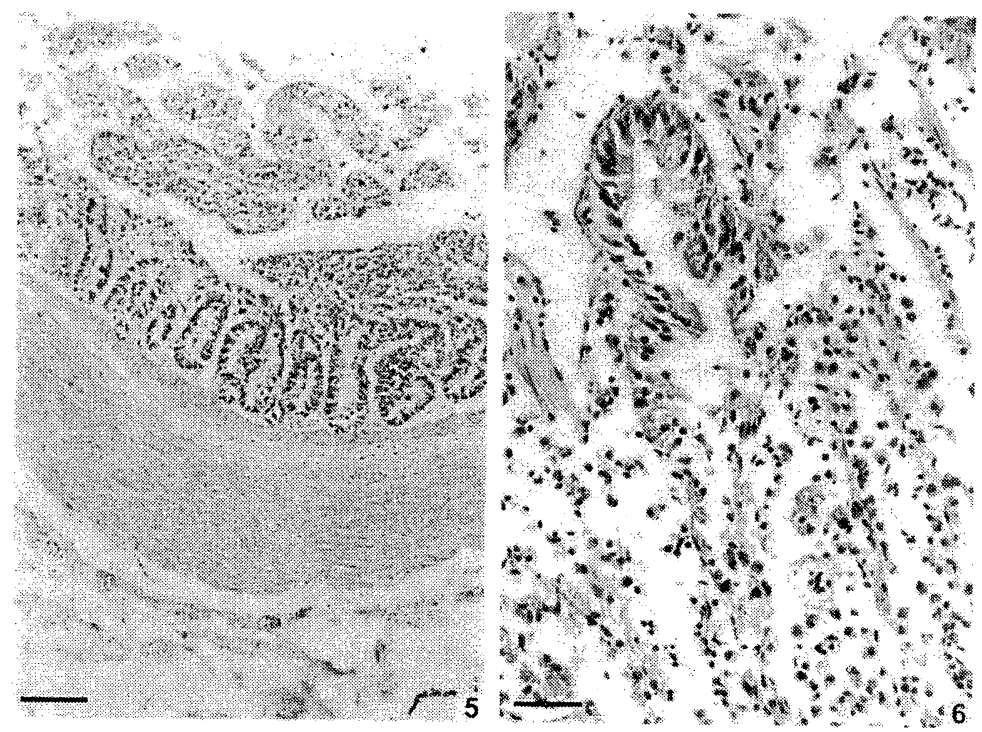

Figs 5-6 (5) Histological section of the small intestine of a hyacinth macaw ( $A$. hyacinthinus), parasitized with the nematode $A$. hermaphrodita showing an accentuated erosive process on the mucosa due to the mechanic action of the parasites. Bar $=0.05 \mathrm{~mm}$; (6) Histological section of the small intestine of a hyacinth macaw ( $A$. hyacinthinus) parasitized with the nematode $A$. hermaphrodita, showing inflammatory cells infiltration with predominance of granulocytes (heterophils and eosinophils). Bar $=0.02 \mathrm{~mm}$.

\section{References}

FREITAS, J. F. T.; MENDONÇA, J. M. Aprocta pyrmuraen. sp. (Nematoda, Filaroidea) Rev. Bras. Biol.v. 12, p. 385-388, 1952.

FORSHAW, J. M. Parrots of the world. Neptune, New Jersey: T. F. H. Publications, Inc., 584 p., 1977.

MARTINEZ, F. A.; J. C.; TROIANO; J. L.; BINDA, A. SANTA CRUZ. Infestación por Capillariay Ascaridia spp. en psitácidos de criadero. Rev. Med. Vet.v. 80, p. 24-26, 1999.

PEREIRA, C. Novo nematóide parasito de psitacídeos. Rev. Med. Cir. S. Paulo v. 1, p. 3-6, 1933.

PINTO, R. M.; VICENTE, J. J.; NORONHA, D. Nematode parasites of Brazilian psittacid birds, with emphasis on the genus Pelecitus Railliet
\& Henry, 1910. Mem. Inst. Oswaldo Cruz v. 88, p. 279-284, 1993.

PINTO, O. M. O. Novo catálogo das aves do Brasil. $1^{\text {a }}$. Parte. São Paulo: Empresa Gráfica da Revista dos Tribunais, 446 p., 1978.

SERRA-FREIRE, N. M., BIANCHIN, I. Sobre quatro espécies de Ascaridia (Dujardin, 1845) parasitas de psitacídeos, com citação de um novo hospedeiro para $A$. hermafrodita (Froelich, 1789) Nematoda:Ascaroidea) no Brasil. Atas Soc. Biol. Rio de Janeirov. 19, p. 51-54, 1978.

TRAVASSOS, L. Fauna helmintológica dos "Psittacidae" do Brasil. Arch. Inst. Biol. São Paulo v. 3, p. 5-20, 1930.

VICENTE, J.J.;H. O.RODRIGUES; D.C. GOMES, R. M. PINTO. Nematóides do Brasil. Parte IV. Nematóides de aves. Rev. bras. Zool. v. 12 (Supl. 1), p. 1-273, 1995. 